\title{
RADIOAKTIEWE UITSTRALINGS EN HULLE BETREKKING OP DIE BESTAANSVOORWAARDES VAN DIERE*
}

Die vorm en funksie van enige lewende organisme is enersyds 'n manifestasie van oorerflike intrinsieke faktore wat inherent kenmerkend van sy samestelling is en andersyds 'n nitdrukking van die invloed van ekstrinsieke faktoric wat aan die werking van omgewingstoestande toegeskryf moet word. Aangesion erflike en omgewingsfaktore in gedurige wisselwerking met mekaar verkeer, is die lewe eintlik 'n uitdrukking valı 'n voortdurend variërende ewewig tussen hierdie twee kragte. Biologicse navorsing is dus nie leperk tot die ondersoek van slegs die morfologiese on funksionele aspekte van die organisme nie, maar dit trag ook om die probleme van die ingewikkelde verhoudings tussen die organismes en hulle fisiese ongewing on dic ondorlinge verhourlings tussen plant, dicr en mens te probecer ontrafel.

Moderne ekologie ontlexd die omgewingsinvloede tot in liulle eenvoudigste eenhede en bepal die watarle van elkeen, nie slegs kwalitatief nic, maar ook kwantiatief. Dit hring onvermydelik mee dat die dierekoloog ook die sfeer van die plantkunde, die skeikunde, die fisika, die statistiek, die geologie, die meteorologie, die hidrografie, die bodemkunde el nog ander natuurwetenskappe self moet hinnegaan of hulp van sodanige dissiplines moet ontvang. Hierdic uitvoerige analise is nie beperk tot slegs die omgewing nie, maar dit word uitgebrei tot 'n studie van die reaksies van die organismes op) variasies in die omgewingstoestande. Die waarde van sodanige reaksies moet weerecns met behulp van noukeurige kwalitatiewe en kwantitatiewe fisiese en chemiese ondersoeke vasgestel word.

Een van die afdelings van die moderne ekologie waar die ekoloog homself onmiddellik op dic gebied van die fisikus hevind, is radioekologie. Die snelle ontwikkeling van atoomenergie vir militêre en vredestydse gehruik en die versj)reiding van potensieel gevaarlike radioaktiewe stowwe in die omringende omgewing, het hierdie vakgebied van primêre belang gemaak. Radio-ekologie is 'n studie van die invloed van uitstraling op indiwidue, bevolkings, gemeenskappe en ckostelsels sowel as 'n ondersoek na die lot van radioaktiewe stowwe wat in die omgewing

\footnotetext{
* Inougurele Rede gelewer by die aanvaarding van 'n professoraat in Dierkunde aan die Potchefstrommse Universileit vir C.II.O., deur dr. P. A. J. Ryke, op Viydag 5 April 1963.
} 
vrygelaat word, en die wyses waarop die ekologiese gemeenskappe on hevolkings die verspreiding van radioakliwiteit beheer.

Jit is vir die mens van hierdie atoomeeu uiters noodsaaklik om kennis te dra van die uitwerking wal bv. radioaktiewe stronsium en jodium na atoombomontploffings op die biologiese wêreld het. Van nog meer aktuele belang is die invloed en lot van radioaktiewe stowwe wat in gronde en natuurlike waters as atoomafval neergelê word. Baie organismes neem hierdie stownc op en konsentreer dit in lulle weefsels, 'n toestand wat, ats die konsentrasie hoog is, verskillende biologies belangrike geleurtenisse, soos die induksie van mutasies, kankers on selfs die dood, tot gevolg kan hê. Maar ook die invloed van selfs die heel verdunde hoeveellıede radioaktiewe stof wat tans in baie omgenings voorkom, is nog feitlik onbekend. Dic omstandigheid dat die bioloog ook van hierdie radioakliewe stowne gebruik kan makk om tot nou toe ontoeganklike geheimenisse van die lewensprosesse en lewensaktiwiteite van organismes te kan ontrafel, gee aan die radio-ekologie 'n status en belangrikheid waarvan elke bioloog in die besonder, matar ook alle natuurwetenskaplikes in die algemeen, kennis moet dra.

\section{EKOLOGIES BELANGRIKE KERNFISIESE, BEGRIPPE}

\section{Ioniserende uitstralings}

Uitstralings soos lig, wat gewoonlik deur organismes vir hulle voordeel gebruik word, dra relatief klein hocveellede energie en doen baie min of glad geen skade aan die organismes wat dit alssorbeer nie. In teenstelling met hierdie onskadelike uitstralings is daar ander wat die vermoë besit om elektrone vanuit atome te verwyder en hulle aan ander atome te koppel, sodat positiewe en negatiewe iompare geproduseer word. Dit word algemeen aanvaar dat ionisering die hoofoorsaak van protoplasma-beskadiging is en dat die mate warin sodanige ioniserende uitstralings skade aanrig, in direkte verhouding is tot die aantal ioonpare wat in die alsorberende stof gevorm word. Twee van die drie ioniserende uitstralings wat van primêre ekologiese belang is, is korpuskulêr (alfa en leta) terwyl een elektromagneties is (gammauitstraling en die verwante $\mathrm{X}$-strale). $\mathrm{Ml}$ drie tipes uitstraling word vanuit radioaktiewe stowwe op) die aarde uitgestuur of vanuit die buitenste ruimte ontvang.

Korpuskulêre uitstraling hestaan uit strome atoom- of subatoomdeelijies wat hulle energie oordra op enigiets waarteen hulle stuit. Omdat hulle 'n bepaalde massa besit, beweeg die deeltjies net 'n kort afstand deur die lug of stof, maar waar hulle gestuit word, vind 'n groot mate van lokale ionisering plaas. Die relatief groot alfadeeltjies is dele van heliumatome wat slegs 'n paar sentimeters in lug heweeg en maklik gestuit word 
leur 'n dun papier of die dooie lae van die vel van mens of dier. Betadeeltjies, wal haie kleiner is, is elektrone wat teen 'n hoë snellheid beweeg en die vermoë besit om 'n aantal voet in lug te beweeg of 'n paar sentimeters in weefsel in te dring.

Ioniserende elektromagnetiese uitstralings, aan die ander kant, is soos lig, maar net van haie korter golflengte. Hulle heweeg oor groot afstande, dring stowwe geredelik bime en versprei hulle energie oor lang en verskeie roetes. Gammastrale dring biologiese materiaal maklik limne en 'n bepaalde ,straal" kan of regdeur 'n organisme gaan sonder om rnige nitwerking te hê if dit kan ionisering langs 'n lang roete voortbring. Die einllike effek hang grootliks af van die aantal en energie van die strale en die afstand wat die organisme hom van die uitstralingsbron hevind, want intensiteit neem eksponensicel met afstand af.

Dic alla, heta, gamma-reeks neem dus toe in indringingsvermoë, mar daar is weer 'n afname in konsentrasie van ionisering en lokale heskadiging. Bioloë klassifiseer dus radioaktiewe stowwe wat alfa- of hetadeeltjies uilstuur dikwels as "interne senders", omdat hulle effek walarskynlik die grootste sal wees wanneer hulle of geabsorbeer, geëngesteer of op een of ander manier inwendig neergelê word, of wanneer hulle op die maklik deurdringbare oppervlak van klein ,onbeskutte” diere soos mikroörganismes te lande kom. $\Lambda$ an die ander kant word radioakliewe stowwe wat primèr gamma-uitsenders is „eksterne senders” genoem, aangesien hulle indringend is en effekte kan voortbring sonder dat hulle in die inwendige dele van die organismes ingeneem hoef te word. Die effek van gamma-uitstraling van hinne of beta van buite-af, kan eyter nic in radiobiologiese ondersoekc buite rekening gelat word nie.

\section{Radio-isolope}

i)ic indringingsvermoë van nitstraling staan in direkte verband met sy energie. Die meerderheid radlio-isotope wat van ckologiese belang is, het energiewaardes tussen 0.1 en 5 miljoen elektronvolts (Mev) en hoe groter die energie hoe groter is die gevaar vir biologiese materiaal wat bime trefafstand ran die hepaalde tipe uitstraling is. $\Lambda$ an die ander kant is dit weer makliker om minimale hoeveellede van die energieryke isotope op te spoor, sodat hulle dus geriefliker as spoorvormers in biologiese navorsing gehruik kan word.

Vamuit in ckologiese standpunt gesien, kan radio-isotope in vier min of meer goed-afgebakende groepe ingedecl word.

(1) Natuurlik-voorkomende radio-isotope: Dit sluit in Uranium-235, Lranium-238, Radium-226, Torium-232, Kalium-40 en Koolstof-14. Die ioniserende uitstralings van hierdie natuurlike radioaktiewe stowwe in yroml en water, tesatme mot kosmiese strale, vorm die sogenaamde ,agter- 
gronduitstraling" waraan die organismes wat tans op die aarde leef, aangepas is. Dit is selfs moontlik dat die mens en die diere en plante van hierdie uitstralings afhanklik is vir die hehoud van hulle genetiesc plastisiteit. Ondat hierdie agtergronduitstraling heelwat verskil in verskillende dele van die biosfeer, kan dit 'n belangrike bepalende faktor in die geograliese en stratigrafiese verspreiding van organismes op die aarle wees.

(2) Radio-isolope van elemente wat noodsaaklike bestanddele van organismes is: Hierdie groep is nie slegs helangrik a.g.v. die uitstralings wat luulle voorthing nie. maar ook weens hulle gebruik as spoorvormers in ekologiese studies soos bv. gemeenskapmotaholisme. I)it sluit in Kalsium4.5, Kinolstof-1.1, Koper-64. Jolium-131, Yster-59, Trilium, Mangata-54, Fosfor-32, Kalium-12, Natıium-22. Natrium-21, Swawel-21, Swawel-35, Sink-65, Barium-1H), Broom-82, Koloalt-60, Molihdeen-99 en ander spoorelemente.

(3) Radioaktiewe neerslag en afvalstowwe: Hierdie groep isotope is belangrik in splitsingsprodukte wat dic biosfeer binnekom a.g.v. radioaktiewe neerslag of deur die verwydering van atoomafval. Met uitsonlering van Jodium-1.31 is dit elemente wat nie noodsaaklik in die metaholisme van organismes is nie. Hierdie isotope is egter die gevaarlike groep, aangesien bulle in groot hoeveclhede geproduseer word deur kemontploffings of heheerde kernoperasies wat kermkrag of ander nuttige vorme van encegie voortbring. 'n Aanlal van dic isotope het 'n dogterisotoop wat gedurende hulle onthinding gevorm word on wat soms selfs mecr cnergieryk as die ouerisotoop is: Stronsium-90 en Yurium-90, Stronsium-89). Sesium-137 en Barium-137. Sesium-131. Serium-141 en Prascodimium-14.t. Serium-IA, Rutenium-Io6 en Rodium-106, Rulenium-103, Sirkonium-95 (n Niohium-95, Barium-140) en Iantaan-140, Ncodimium1:17 en Prometium-147, Ytrium-91, Plulonium-239, Jodium-131, Uraan235 en Uraan-238.

Hoewel die meeste van hierdie isolope nie mondsaaklike beslanddele van protoplasma is nie, gedra baie van hulle hulle op in clremies soortgelyke wyse as essensiële elemente, sodat hulle ook in lewende stelsels gekonsentreer word. So hv. omdat stronsiunisotope lualle net soos kalsium gedra, gaan hulle geredelik voedselkettings binne en veroorsalk 'n ophoping in die radiosensitiewe beenmurgueefsel van die hene van die mens en die werweldicre.

1.) Etiketterrisotopo: Hicrolie groepie is isotrope wal haie multig gebruik kan word om dicre tc merk of etiketteer, angesien luulle energicryke gammastrale uitstraal wat oor 'n alstand opgespoor kan word: Kobalt-(o), Skandium-10 en Tantal-li2. 


\section{BESOEIDELING VAN DIE BIOSFEER}

Putensiële qevare verbonde an radioaktiewe besoedeling van die liosfeer kan in twee hoofgroepe verdecl word. Die cerste ontstan a.g.v. radioaktiene stof wat as 'n neerslag na atoombomontploffings op die aarde val en die tweede spruit voort uit alvalstowwe wat deur installasies vir die produhsie van atoomenergie in die omringende omgewing vrygelaat word.

\section{Radioakliewe neerslag}

Hoewel ons hier in die Republiek van Suid-Afrika tans nog redelik gevrywaar is van die effekte van radioaktiewe stof wat deur atoombomme uitgewerp word, moet ons ons nogtans deeglik vergewis van die moontlike gevare wat dit vir mens. dier en plant kan inhou. Die biologiese wêreld is so 'n ineengestrengelde cenheid, hoofsaaklik a.g.v. die ekologiese voedselkettings, dat daardie dinge wat die plant uit die abiotiese omgewing ontvang of direk of indirek d m.v. diere op die mens oorgedra word. I)it aal dus 'n vrugtelose pogging wees om die mens teen uitstraling te probeer heskerm sonder dat al die kategoricë van die organismewêreld deeglik in 'n sodanige program ingesluit word.

Ten lye van atoombomontploffings is Koolstof-I4 die hoofproduk van die reaksies, maar a.g.v. sy swak beta-aktiwiteit en uitgebreide verdumning. hou dit geen of haic min gevaar in. In die meeste gevalle was dit die splitsing van uranium nat hoofsaaklik vir omgewingshesocdeling verantwoordelik was. Radioakticwe neerslag wat deur wapens vrygestel word, verskil van die gewone atoomalvalstowwe daarin dat dit in dic vorm van relatief onoploshare dechjies voorkom, angesien die isotope versmelt is met yster, silika, stof en ander dinge wat toevallig in die omgewing van die ontploffende bom is. Hierdie deeltjies, wat onder die mikroskoop soos klein verskillend-gekleurde deeltjies lyk, varieer in prontte van "I paar honderd mikron tol byna kollö̈dale dimensies. Hoewel meeste van die: radioakliewe dectijies langs in hepaalde baan beweeg en dan op) die aarde necrsak, kan die kleiner deeltjies vir 'n lang tyd nog rondom die aarde beweeg. Uit 'n ekologiese oogpunt is dit dus 'n belangrike faktor om in gedagyte te loou dat daar 'n vertraging, soms selfs van jare, kan wees vootdal hierdie stof die biologiese stelsels binnegaan en kill affekterer.

Een van die verrassende ontdekkings wat in die omgewings van ontploffings gemaak is, is dat plante en diere wat 'n 100 myl of meer weg van die middedpunt hulle bevind het, selfs meer van sekere isotope gealssorbeer het as indiwidue van dieselfde spesies wat so te sê in dic skadu van dic bom geteef hel. Volgens Nishia and Larson (1957) is hierdie feil herhaddelik deur radio-ekolö by die Nevada-toetsterein in 
die V.S.A. vasgestel. Die verklaring van hierdie verskynsel lê waarskynlik daarin dat die kleiner deeltjies wat verder deur die lug beweeg makliker oplosbaar is en dus gou deur die organismes geabsorbeer word.

By 'n ondersoek van die wêreldwye neerslag van radioaktiewe stof is die teenwoordigheid van drie splitsingsprodukte nl. Sr-90, I-131 en Cs-137 reeds in 1957 in menslike weefsels vasgestel. Dit dui dus daarop dat neerslagisotope die voedselketting van die mens net so maklik as die van diere kan linnegaan. Sesium stem met stronsium in dié opsig ooreen dat hulle beide gasvoorlopers het en dus met ..langafstandneerslag" geassosieer word. Sesium gedra hom sons kalium en word geredelik deur organismes geabsorbeer maar, in teenstelling met stronsium, bly dit slegs vir 'n kort rukkie in die liggaam. Radiojodium, wat in groot hoeveelhede deur wapens en reaktors gevorm word, het 'n wye verspreiding, kleef maklik aan plante vas, en word vinnig via die voedselkettings in die skildkliere van werweldiere gekonsentreer. Nieteenstaande sy kort halflewo hereik dit tog die end van die voedselketting, nl. die werweldiere of die mens. Na elke reeks kernwapentoetse is vasgestel dat die I-131-hoogte in die skildkliere van plaasdiere en, tot 'n mindere mate, ook die mens, toegeneem het.

Sover vasgestel kon word, is die inwendige konsentrasie van bogenoemde drie isotope by die mens tans nog onderkant die vlak wat as skadelik beskou word. In die algemeen hou uitstraling dus nog nie 'n gevaar in nie, maar lokale toestande kan skielik ontwikkel wat die prentjie drasties kan verander. Caster (1957) stel selfs die moontlikheid dat die maksimum toelaatbare vlak wat nog redelik veilig vir die mens se gesondheid is, oor 'n tiental jare oorskry kan word. 'n $\Lambda$ Igemene gevolgtrekking wat gemaak word is dat vleiseters waarskynlik minder las van radioisotope sal hê as planteters, want sowel die werking van diskriminerende prosesse as die tydsverloop langs dic voedselketting bied gelecntheid vir radioaktiewe ontbinding.

\section{Verwydering van atoomajval}

Hoewel dit eintlik die radioaktiewe neerslag van oorlogswapens is wat die meeste aandag van die publiek geniet. is die afval in die vredesgebruik van atoomenergie potensieel 'i haie groter probleem. Daar word tans nog te min aandag aan die ekologiese invloed van die verwydering van afvalstowwe bestee, 'n aspek wat miskien die bejerkende faktor vir die volledige eksploitasie van atoomenergie kan wees. Die potensiëlc gevare vir die mens sc biologiese omgening kan in twee kategoricë verdeel word. Die eerste is die direkte gevaar. Radioaktiwe stowwe wat direk met huis-, plaas- en wilde diere in aanraking kom, kan ongunstige effekte meeloring en, as genoegsame hoeveelhede afvalstowwe teenwoordig is, kan dit 'n afname in die bevolkings tot gevolg liĉ. Die tweede gevaar 
is indirek, maar van groter belang as die eerste. Dit staan i.v.m. radioaktiewe stowwe wat via biologiese voedselkettings op die mens oorgedra kan word. $\Lambda$ angesien hoë-vlakse afvalstowwe in spesiale groot houers gestroor word, is hulle eintlik nie hier ter sake nie. Die lae-vlakse afvalstowwe wat egler in die omgewing vrygelaat word omdat hulle massa te groot is om geberg te word, gaan wcl deeglik die sfeer van die ekoloog binne. Aangesien die isotope maar die gewone weg van die voedselketting neem, is dit veral belangrik om vas te stel op watter wyse die stowwe deur plante opgeneem word en watter omgewingsfaktore die tempo van opname beïnvloed. Romney et al. (1957) het lv. alreeds vasgestel dat. onder eksperimentele toestande, die grondtipe en die soort plante 'n proot rol in die opneemtempo speel.

Van die verskeie beskermingsmaatreëls wat in gebruik is om veiligheid t.o.v. radioaktiewe afvalstowwe te verseker, is die sogenaamde ..biologiese waarskuwing" eell vall die betroubaarste. Daar is twee tipes ran biologiese waarskuwing en allei maak van organismes as indikatore gelruik (Kornherg, 1958). In die een geval word geselekteerde eksemplare, onder beheerde laboratoriumtoeslande, blootgestel aan produksieaflope met hoër konsentrasies as die wararmee die organismes in hulle natuurlike habitat te kampe sou hê. Sodoende word die maksimum konsentrasie afval wat geen toksiese effekte op die organismes van die omgewing sal hê nie, vasgagestel. In die tweede geval word die hoeveelheid radioaktiewe elemente in die plaaslike wilde plante en diere vasgestel sodat dit as 'n aanwysing kan dien om die gevare van besmetting van die omgewing, daclelik die loof tc bied. Die organismes wat in 'n natuurlike gemeenskap dir meeste deur die hesmettende radio-elemente geaffekteer word, word uitgesoek en hulle dien dan as indikatore by toekomstige roetine-ondersoeke.

Dit wil voorkom of putte in die grond tans in die meeste gevalle die mees ekonomiese en gerieflikste manier is om van lae-vlakse afvalstowwe ontslar te raak. Met die oog op die talle laboratoria en klein installasies wat wararskynlik in die toekoms dwarsoor die wêreld tot stand sal kom, is 'n studie van die beweging van afvalstowwe deur die grond en die moontlikheid dat dit plantwortels of die watertafel kan bereik, van die allergrootste belang. So het Brown et al. (1956) vasgestel dat by die Hanford-installasie rutenium relatief gou tot naby die diep watertafel van die hall-woestyngelied beweeg het. By Oak Ridge het dieselfde isotoop werr oor 'n groot afstand horisontaal heweeg vanaf die afvalputte en uiteindelik in die hlare van bome verskyn (Krumloolz, 1954). Dit was 'n baie onverwagte en onaangename ontdekking, en dit het onmiddellik duidelik geword dat intensiewe biologiese veldstudies in sodanige gevalle altyd noodsaaklik is.

Jic moontlikheid om grootskaalse atoomafval in die see te deponeer, 
word tans nog onclersock. maar kleinskaalse toetse is alreeds in verskeie dele van die nêreld uitgevoer. Aan die een kant is die verdumningsfaktor il groot voordeel, mar dic nejging van baie organismes om die isotope in luulle liggame to konsentreer, veral in die vlakwaters langs die kus wata littorale organismes geoes word, skep dadelik weer probleme. So h. het boligman and Dunster (1956) vasgestel dat slegs in palar curies per dag met veiligheid in die lerse see viygelaat kan word, 'n gevolgtrekking wat gehaseer is op die omstandigheid dat daar 'n ophopingsmeiging van isotope in kommersieel holangrike seegewasse en mariene organismes voorkom.

\section{(OEVOELICHEII) VAN ORGANISMES VIR RAIDOOAKTIEIEE UITSTRALING;}

Daar is feitlik niks bekend angaande die moontlike uitwerking van volgehotie lae-vlakuitstralings op ekostelsels nie, maar in ansienlike hoceveelheid gegewens is reeds versamel oor dic gevoeligheid van organismes vir radioaktiewe uitstraling. Selfs voordat die geweldige helangstelling in die biologiese uitwerking van ioniserende uitstralings gedurende die afgelope vyftien jaar hegin het, is heelwat navorsingswerk mot X-strale gedoen, watdeur aanduidings gelewer is dat organismes, t.o.v. hul vermoë om groot dosisse te kan verdra, haic van mokail verskil. X-strale is elektromagnetiese uitstralings. baie soortgelyk aan gammastrale, maar luble nord nie vanuit radioaktiewe stowwe wat in die omgewing versprei is, uitgestuur nie. Aangesien hulle dieselfde effek as gammastrale het, en maklik bekombaar is in bv. "n X-straalapparaat, kan hulle baie gerieflik in eksperimentele studies oor indiwidue, bevolkings en selfs kleiner ekostelsels gebruik word. Dit moct egter henadruk word dat dosisse wat in navorsingseksperimente gelruik word haie hoër is as wat organismes normaalweg in die natuur mee te kampe het.

Odum (1959) het die gevoeligheid vall drie geheel verskillonde grorpe organismes nl. soogdiere, insekte en baktericë t.o.v. rnkele dosisse X- of gammauitstraling, ondersoek. Volgens hierdie outenr se resultale word die vcrdelingsnelheid vain 'n sensitiewe mikrö̈rganisme deur 'n dosis van $10,000 \mathrm{rad}(1 \mathrm{rad}=$ geabsorbcerde dosis van 100 erg energic per gram wrefsel) beïnvloed, terwyl 'n rlosis van I miljoen rad of selfs meer nodig is om alle bakterieë, insluitende spore en ander weerstandbiedende stadia, te vernietig. $O_{p}$ soortgelyke wyse sal 50)() rad sommige inseksoorte steriliseer, matr $100,000 \mathrm{rad}$ is nodig om alle inctiwidue van die mecr meharde spesies dood te maak. Volgens dieselfele algemene kriteriums is soogdiere die sensitiefste van alle organismes pu sal deur 1000 rad uitgewis word, terwyl die lacr werweldicre effens meer weerstandbiedend is. Uit 'n ekologiese oogpunt beskou is. volgens Odum, bogenoemde voorstelling egter haie misleidend, aangesien selfs die geharde organismes 
- ladiums in hulle lewensiklus. of kritieke periodes in hulle bevolkingsgroei hel, wal deur baic kleiner dosisse gealfekteer word. So is hv. vasgestel (lal vir Drosophila, een van die meer neerstandbiedende insekle, 'n dosis valu ongrever $10^{\circ}$ rad modig is om die helfte van die volwasse vlië̈ dood 10. mak $\left.(1,1)_{50}\right)$, terwyl slegs 163 rad die helfte van die indiwjdue sal verniclig as blootstelling gedurende die sensiliefste stadium in die ontwikkcling (nl. die cier gedurende kliewing) geskied. Selfs so 'n lae dosis as 8 rad per dag kan 11 meenhare effek op die groei en ontwikkeling van sekere sprinkanuneurohlaste hê. Diesolfde algemene verskynsel is ook ly plante wairgeneem.

Die tesultale van navorsing dui daarop dat gevoeligheid vir radioaktiewe uilstraling afnecm met loenemende ouderdom en dat die vroeë ontwikkelingstadiums. wamnees alle selle vimnig verdeel, dikwels veral baie kweshar is. Jong kinders onder die ouderdom van vier jaar gaar $\$ r-90)$ lr. heelwat vimniger op as volwassenes en is dus blykbaar meer I doliosensitief. Daar is ook anduidings dat dit ook op groter komponente sous in hele dierbevolking wilt vinnige vermeerdering ondergaan, van locpassing is. Selfs lae-vlakuitstralings het gedurende hierdie periodes 'n invloed op organismes, terwyl taksomomiese verwantskappe blykbaar nie licer 'n rol speel nie.

Een rede waarom hevolkings van klein organismes meer weerstand Iren $X$ - en gammauitstraling bied, is die omstandigheid dat hulle biomassa $\therefore$ klein per eenheid volume van die omgewing is, dat daar relatief min l'wende slo[ is wat die energie kan ahsorbeet. Dat liggaamsgrootte egter nic die enigsle faklor is wat hierloy betrokke is nie, blyk duidelik uit Puck an Marcus (1956) se warnemings dat geisoleerde soogdierselle moer semsitiel is as mikroöryanismes van ongeveer dieselfde grootte. Daarbenewens het klein organismes ook 'n hoë voortplantingspotensiaal, sodal hulle vinnig kan herstel van die skade wat an die hevolking aanarrig is. $\Lambda$ s $90 \%$ van die mikroörganismes bv. deur uitstraling gedood word, kan dic oothlynende $10 \%$ baie gou weer die gebied bevolk. As, alan die ander kanl. $90 \%$ van die selle van "n groot komplekse organisme lorskadig word, is dit duidelik dal ly rrie sal kan herstel nie. Die effek van ('lektromagnetiese uitstraling op klein organismes is dus dikwels net e'en nat die bevolking tydelik tot stilstand bring of vertraag. Onder sokere omgewingstoestande kan alfa- en betadecltjies wat in staat is om incusc lokale effekle in klein areas teweeg te bring, egter groter skade aan klein organismes as aan grotes aamrig. So bv. sal 'n soogdiereier wat deur die moeder se liggaamswand heskerm word nie deur 'n hoeveelheid lorta-uitstralende isotupe: wat in die grond gedeponeer is, geaffekteer word nie, terwyl "n sprinkaaneier of 'n grondorganisme die volle intensilrit van die uitstraling sal ondervind.

'n Vorskyusel wal selfs intoressanter is as die verskil in radiosensi- 
tiniteit Lussen uitemlopende diergrope. is die treffende verskille wat hy taksonomies verwante organismes optree. Jonkins (1957) het vasgestel dat vir die vlieg Callitroga 'n dosis van $500($ rad $X$ - of gammatritstraling newlig is om $100 \%$ sterilisering teweeg to bring. terwyl vir ander insekte soos Mabrabracon, Drosophila en Lyc/1!s 750), 16.0000 en 32.000) rad respektiewelik nodig is. Solls indiwidue en veral rasace of subspesies van dieselffe spesie kan 'n groot mate van verskil in verdraagsammleid t.o.v. uitstraling vertoon. I)ie gevoeligheidsvariasies ly verskillende rasse van lahoratoriummuise is welloekend. Rugh and Wolff (1953) het bv. gevind clat swart muise minder sensitief vir uitstralings is as wit muise, terwyl in kruisingseksperimente tussen die twee rasse vasgestel is dat die nakomelinge meer weerstandbiedend is as heide die wit en swart ouers.

Verskil in weerstandsvermoë teen uitstraling is van groot ekologiese belang. As die natuur 'n hoër vlak van uitstraling ontvang as waaraan hy gewoond is, sal aanpassings van die organismes noodwendig moct volg. en sensitiewe rasse of spesies sal uitgeskakel word. As die geëlimineerde organisme-eenheid dan deur in ekologies-ekwivalente groep vervang word - wat dus dieselfde rol in die gemeenskap kan speel - sal dit nie 'n groot uitwerking op die ekostelsel hê nie, d.w.s. as ons aanneem dat die uitgeskakelde komponent nie die mens is nie. As egter aan die ander kant die onderhawige komponente heeltemal verskillend is of tot verskillende trofiese vlakke hehoort, kan dit 'n aansienlike totale effek meehring wat die ewewig in die ekustelsel leeltemal sal versteur. 'n Sodanige verskynsel is deur Auerbach (1958) waargeneem in sy bestralingseksperimente met predatoriese en prooimythevolkings in grond. 1)it het geblyk dat die roofdierbevolking meer gevoelig was en in aantalle afgeneem het, terwyl die prooibevolking. a.g.v. die verslapping in predatordruk, selfs toegencem het. I)ic implikasies wat sulke resultate vir dic torgepaste ekologie inlou, spreek vanself.

Aangesien die mrns hykhaar minstens net so gevoelig vir radioaktiewe uitstraling is as enige dier of plant, hestaan daar 'n gevoel dat, soos Loutit (1956) dit stel: „... if we take sufficient care radiobiologrically to look after mankind, with few exceptions the rest of nature will take care of itself. Sensitivity to ionizing radiation is well correlated with the degree of evolutionary complexity. Thus, man and his domestic mammals will be expected to be among the first to suffer from overexposure to radiation". Dat 'n sodanige veronderstelling heslis 'n onrvereenvoudiging is, hlyk duidelik uit die voorafgaande gegewens. Dit sal ook heteken dat dáárdie groot gedecltes van die biosfeer soos rivier, oseaan en grond, warin die mens nie permanent leef nie, maar geïgnoreer kan word, terwyl dit in werklikheid haie nou by die biogeochemiese kringlope en voedselkettings ingeskakel is. 


\section{OPHOPING VAN RADIOAKTIEWE ISOTOPE IN VOEDSELKETTINGS}

Wanneer radio-isotope in die omgewing vrygelat word, versprei hulle gewoonlik, sodat die biota in haie verdunde vorm met hul in aanraking kom. Soms geheur dit egter dat hulle onverwagte bewegings uitvoer en op sommige plekke in die ekostelsel ophoop. Hoewel isotope dus tot 'n relatief onskadelike vlak verdun kan word wanneer dit in die omgewing vrygelaat word, kan hulle tog deur organismes of 'n reeks organismes tot 'n kritieke punt gekonsentreer word. Met ander woorde die mens kan aan die natuur in skvnbaar onskadelike hoeveelheid radioakliwiteit gee en dit dan. soms wamneer hy dit die minste verwag, in 'n dodelike pakkie terugkry.

Een van die intensiefste ondersocke van 'n ekostelsel waar opeenloppingsneigings in sekere voedselkettings voorkom, is gedoen in dic Columbiarivier. W'ashington, waar die Hanford Atoominstallasie geleë is. Volgens Hanson and Komberg (1956), Foster and Davis (1956) en Kornberg (1958) word hierdie omgewing op drie verskillende maniere deur radioakliewe stowwe hesmet. Baie klein hoeveelhede hoogs oploshare radioaktiewe isotope word teen in konstante tempo in die water vrygelatat, eintlik as normalc hestanddele van water wat slegs radioaktief geword het deur induksie walar die water deur die reaktors vloei. Hierhenewens bereik radioaktiewe stonwe ook die lokale omgewing d.m.v. afvalgasse, veral I-131 wat in die lug vrygelaat word, terwyl 'n derde tipe lesmetting geskied via die afvalvloeistowwe, wat splitsingsprodukte bevat.

Dic resultate van die ondersoeke by die Hanford-installasies het aangetoon tot watter mate konsentrasie van isotope in die plante, insekte ('n ander ongewerweldes, en werweldiere. plaasgevind het. Die sogenaamde komsentrasiefaktor. d.w.s. die verhouding van 'n radio-isotoop in die organisme tot die in die omgewing. was in sommige gevalle verrassend luog. So bv. is vasgestel dat die hoeveellieid stabiele fosfor in die eierdroier van die watervoëls in die omgewing 2 miljoen keer hoër as in die waller van die Columbiarivier was. 'il Mens sou nie verwag om net so 'n hoë konsentrasiefaktor vir radioaktiewe fosfor te kry nie aangesien, terwyl dit deur dic voedselketting na die eiers beweeg, daar'n groot mate van onthinding sal plaasvind wal die hoeveelheid aansienlik sal verminder. Tog is soms 'n konsentrasiefaktor so hoog as $1,500,000$ aangeteken; die gemiddelde was egter laer.

Hoewel radioaktiwilej! nie die opmeem van isotope deur lewende stelsels inë̈nvloed nie, kan dit natuurlik die weefsels affekteer sodra dit gealosorbeer is. In die geval van hogenoemde eiers was die hoeveelheid in die eier. ten spyte van die hoë konsentrasie, nog nie genoeg om die uithrocibaarheid te verminder nie. As die konsentrasie fosfor-32 in die rivierwaler egter toegelaat sou word om die maksimum toelaathare hoogte vir drinkwater te bereik (in plaas van om heelwat onderkant hier- 
die hoogte gehou te word), sal die voëls en eiers sekerlik heskadig word en dus ook ongeskik vir menslike gebruik wees. Dit is dus duidelik dat die moontlikheid van ekologiese konsentrasie van radioaktiewe isotope altyd in berekening gebring moet word, terwyl isotope wat natuurlik in sekere weefsels gekonsentreer is soos hv. jodium in die skildklier en stronsium in die been, en/of dardie isotope met 'n lang effektiewe halflewe, klaarhyklik diesulkes is waaroor 'n wakende oog gehou moet word.

Die konsentrasiefaktor sal ook neig om groter te wees in omgewings wat arm a an voedingstowwe is, soos Bryant et al. (1957) bv. hewys het dat skape op arm weivelde meer radiostronsium in hulle bene kry as skape op vrughare weivelde. So ook bv. as die konsentrasie fosfor in die Columbiarivier hoog was i.p.v. laag, sou minder P-32 in die bene en eiers beland het. In die algemeen kan eqter verwag word dat die konsentrasiefakto: hoër in varswater as in die see sal wees en groter in water as op land. Daar is egter nog soveel onbekende kompliserende faktore wat uitsonderings kan voorthring, dat veralgemenings met groot versigtigheid gemaak moet word.

\section{BENUTTING VAN RADIOAKTIEWE UITSTRALING IN EKOLOGIESE NAVORSINC}

\section{Aktiewe bestraling}

Die gewoonte van haie plaaginsekte, warmee die boshou te kampe het, om hulself in die plantweefsel te verberg, skep, talle probleme i.v.m. navorsing oor hul ontwikkeling cn gedrag asook die vasstelling van hevolkingsdigtheid. Die ondersoek van hout, bas- of boomtoppe om die insekte te lokaliseer en hulle getalle vas te stel, bring altyd mee dat die medium warin hulle leef, vernietig word. Verskeie tegnieke vir die kunsmatige teel van sodanige insekte is alreeds in die verlede beproef, maar hulle is dikwels onsuksesvol en bly in elk geval onnatuurlik om die ontwikkeling en gedrag van insekte te bestudeer. Geencen van hierdie metodes is bv. hevredigend om 'n ekologise ondersoek van die bevolkingsdinamika uit te voer nie.

Berryman and Stark 11962 , het eyter gevind dat die gel,ruik van $X$-strale toegang verleen tot moontlikhede om die houtloorderinsekte en ander parasiete in situ te bestudeer sonder die vernietiging van hul natuurlike habitat. Uitstraling, in die hoeveelhede wat hulle gebruik het, het haie min of geen slegte effek op die organismes gehad nie en uitstekende resultate is verkry in radiografiese opnames van dennehoomkewerlarwes en papies, die rooi terpentynkewer, juweelkewers en die boorgange van verskillende soorte houtboorinsekte. Selfs insekte wat verskillendc soorte sade aanval, kon in situ waargeneem word.

Variasies van radiografiese tegnieke het ook moontlike toepassings 
in die studie van baie klein insekte en ander artropodes soos inwendige parasiete, parasiete en predatore in dieselfde verborge medium as die gasheer, en moontlik selfs in taksonomiese en morfologiese ondersoeke.

Die gebruik om parasiete en ander siekteveroorsakende organismes met bestraling te vernietig of onder beheer te hou is reeds vir 'n hele aantal jare toegepas. Ekologiese ondersoek van die hele ekostelsel waarin sulke organismes voorkom, moet sodanige praktyke egter altyd voorafgaan. Hierdie bestrydingsmetode is met sukses toegepas deur Baumhover et al. (1955) toe hulle sekere insekteplae bekamp het deur die diere an net genoeg gammauitstraling hloot te stel om hulle steriel te maak. $O_{p}$ 'n soortgelyke wyse het Dennis (1961) vasgestel dat insekte wat gehergde voedselprodukte hesmet suksesvol hestry kon word deur gammauitstraling, 'n proses wat moontlik gemaak is deur die afvalstowwe van kernreaktors te henut. Ook is onlangs deur Villella et al. (1961) vasgestel dat muise wat eksperimenteel met die serkarieë van die Bilharzia-parasiet, Schistosoma mansoni, hesmet is, 'n immuniteit vir herinfeksie ontwikkel het nadat die eerste serkarieë aan kobalt-60-bestraling blootgestel is. Intensiewe navorsing i.v.m. die gevoeligheid van beide gasheer en parasiet t.o.v. verskillende radioaktiewe uitstralings is egter noodsaaklik voordat 'n algemene grootskaalse, gebruik van hierdie hestrydingsmetodes moontlik sal wees.

\section{Spoorvormers}

Dic radioaktiewe spoorvormertegniek het alreeds belangrike bydraes gelewer tot ons kennis angaande die juiste aard van baie van die komplekse chemiese reaksies wat in die lewende dier en plant plaasvind, en daar is waarskynlik min biochemiese probleme waar hierdie tegniek nie met vrug toegepas kan word nie (Francis et al., 1959). As dit gebruik word tesame met nie-isotopiese ondersoeke en as 'n aanvulling vir ander moderne tegnieke soos chromatografie en elektroforese, sal dit ongetwyfeld hydra tot die opheldering van haie van die halsstarrigste probleme van die natuurwetenskap en die geneeskunde. Dit het alreeds sy waarde hewys as 'n werktuig vir diagnostiese doeleindes in kliniese geneeskunde, terwyl dit in 'n wyer veld inligting voortgeloring het i.v.m. intermediêre metaholisme, skildklierwerking, bloedsirkulasie en uitruilings tussen weefsels en liggaamsvloeistowwe wat vir die mediese wetenskap van haie groot waarde was. Deur die gehruik van radioaktiewe en stabiele isotoopspoorvormers word 'n unieke geleentheid geskej vir die bestudering van lewende prosesse onder fisologiese toeslande, en talle ander probleme wat voorheen met geen hoop op sukses aangepak sou moes word, kom nou limne die bereik van ontrafeling.

Isotope het bv. n groot rol gespeel in die opheldering van baie 
probleme i.v.m. plantvocding, en plantfisioloë en grondskeikundiges het alreeds goeie getruik van die isolonpsponvormertegnieke in bemestingondersoeke gemaak. Dit het ook sy toepassings in die farmakologie, mikrohiologie, paleontologic, geofisika en ander dissiplines van die naiuulnetenska], gevind. Isotoopondersoeke het in haie gevalle slegs gedien om standpunte wat lank voor die spoorvormer-era gelualdig is, te hevestig. Selfs hicrlie bydraes moet egter as van groot belang beskon word aangesien haie van die teorieë en hipoteses op haie min meer as omstandigheidsgetuienis borus het. Dit is miskien misleidend en onverstandig om oordrewe aansprake vir enige bepaalde tipe van ondersoek te mak. maa daar hestan regverdiging vir die sienswyse dat die isotoopspoorvormermetode homself sal uitwys as die vrughatarste fisiese tegniek wat sover in hiologrese navorsing loegepas is.

Ternyl die fisioloog dus rechls die radioaktione spoorvormers tot '1 groot mate geëksploitecr het. is die ekolong slegs in die beginstadium om tegnieke binne sy navorsingsgelied te ontwikkel. Dit het egter nou duidelik geword dat hulle torgepas kan word in studies oor die samestelling en funksies van dier-en plantgemeenskappe aangesien, met die nodige voorsorgmatreäls. radioaktiene spoorvormers net so veilig in die veld as in die laboratorium gebruik kan word. I)it moet benadruk word dat navorsing met hehulp van spoorvormers in ekostelsels, net soos in enkele organi=mes. so heplan word dat die hocveelheid radioaktiene dement wat gebruik word haie klein is in vergelyking met die hoeveclheid nie-ladionaktiene element $w$ at alreeds in die stelsel annwesig is. Nogr die radioaktiwiteit nog die bykomende jone versteur dus die ewewig in die stelsel. Die lot van die spoorvormer, wat maklik opgespoor kan word a.g.v. die uitstralings nal dit uitsluur, is blool in weerspiec̈ling van wal mormaalweg met datrdie bepaalde stof in die stelsel gebeur.

Aangesien damme en mere selfonderhoudend is, leen hulle hulle: uitslekend vir sodanige ekologiese ondersoeke en talle eksperimente is bv. al uitgevoer om. met behulp van radiofosfor navorsing te doen oor die sirkulasic van fosfor in watermassas (Hutchinson. 1957). Volgens hierdie metode is vasogestel dat fosfor nie gelykmatig en gladweg van organismes na die omgen ing en terug heweeg nie, maar dat op enige hepalde (volstip die meeste van die fosfor of in organismes of in solicde organiese of anorganiese deeltjies van die bodemsediment van die watermassa, gebonde is. In mere hv. is slegs ongeveer $10 \%$ die maksimum hoveclheid wat in oplosbare vorm gedurende een of ander hepalde lydstip anwesig is. Studies met P-32-behandelde bemeslingnlowwe in landekostelsels vertoon dieselfde hasiese patrone (Comar, 1957).

Op) soortgelyke nyse is geloruik gemalak van Koolstof-14 om dic produktiwiteit en omset van 'in ekostelsel te mect. terwyl Skandium-1.0 ingespan is om rioolafloophesocedeling van seenater by strande gou to 
kan bepaat. Ander radioakliewr isolope bied baie moontlikhede wat nog molersock mocl word, en dit is dus watakynlik dat die volgende antal jare die onlwikkelingr van haic nuwe tegnieke in lierdic afdeling van anlogiese navorsing sal meebring.

in Tegniok wat ook van landlunkundige waarde is en tans in groter mate gohruik word, is om dic ekologiese vrohouding van insekte tot vcrskillende gewasse te hepaal deut die plante met radioaktiewe isotope to hihandel. Die prosedure wat gevolg word is om of die isotope met lrehulp van in sproeier op die plante te spuit sodat dit geabsorbeer kan worl. of deur dit direk in die hepaalde plant in te spuit. Alle diere wall darna radioaklief word. behoort dus sonder Iwyfel aan die voedselkelling wat mel daardie hepaalde plantsourt begin. Jeur herhaling van dieselfile eksperimont met ander plantsoorte, kan dit "il beeld gee van die verhouding van plantetende en selfs predatoriese diere tot die plante warmee hulle op een of ander wyse assosieer.

Die bemutting van radio-isotope om diere te ,merk" sodat hulle bewegings en godrag nagegaan kan word, is 'n metode wat tans baie alandag geniet (Comar, 1955; Pendleton, 1956; Jenkins, 1957; Vogt, 19571. Sekere opvallende kenmerke van radio-isotope mak hulle besonlor geskik om as merkstowwe vir diere gebruik te word. In die eerste plek hied hulle die veordecl bo die gewone sighare ,etikette" dat hulle nic deur die sintuic van diere wargeneem word nie. 'n Tweede belangrike orrweging vir hulle gebruik is die onıstandigheid dat hulle met gemak aill grool groepe diere loegedien kan word sonder die tydrowende manipulasies wat mel vrocëre metodes gepaard gegaan het. In sommige gevalle mak die radio-isotooptegniek dit selfs moontlik dat die organismes wat ondersock word glad nic deur die navorser gesien, gehanteer of weer vorsamel hoef to word nie. 'n Derde groot voordeel van hierdie tegniek is slat die .etikel" eintlik deel van die dier word, sodat indiwidue dwarsdeur die eksperiment herken kan word sonder die gevaar dat die identifikasiemerk verlore kan rakk. Dit is ook moontlik dat, deur van die bekende onlhindingsndheid van 'n radio-isotoop) gebruik te mak, verskillende organismes wat op anterechvolgende tyo losgelaat is, volgens die intensitcil van die radioaktiwiteit wat algegee word, met behulp van instrumente herken kan word.

Die meeste van die navorsingswerk met hierdie merkstowwe is met insekte gedoen (Jenkins. 19.57 I en daar is sells in geslaag om hele natuurlike hevolkings in die veld van sodanige ,etikelte" le voorsien. Barnes 11959) het 'n inseklowolking met radio-isotope gemerk deur die isotoop to meng met 'n sterk reuk- cn smaaklokias, wat op bepaalde plekke gedeponer is. Deur daarna weer lokvalle op verskillende punte op te stel, kon 'n heeld van die vlieggewoontes van dif insekte opgehou word. Soortgrlyke tegnieke is ook al met vrug gebruik in navorsing oor die ekologie 
van insekte wat as oordraers van siektes dien en het dus reeds hulle waarde in die mediese entomologie hewys. Selfs die ondergrondse bewegings van die landhoukundig-belangrike parasitiese inseklarwes is reeds met sukses gevolg, terwyl ons kennis van die ekologie van insekte in dir algemeen met behulp van hierdie metodes aansienlik uitgehrei is.

Vie net die insekte nie, maar feitlik die hele diereryk kan an isotoopetikettering onderwerp word. Die bemoedigende resultate wat uit ekologiese navorsing op Protozoa en ander klein organismes verkry is, gec reeds vir ons 'n voorsmalak van talle mikro-ekologiese ondersoeke wat kan volg. Aan die ander kant is die gebruik van radioaktiewe etikette as implimente om die bewegings van kleiner soogdiere vas te stel, ook vinnig aan die toeneem. Voordat van isotope gebruik gemaak is, moes navorsers net op lokvalle staat maak om die omvang van die tuisgebied van hierdie soogdicre te kan hepaal. Die nuwe tegniek kan egter heelwat meer inligting aangaande die indiwiduele diere verskaf, terwyl die navorsing in die dag of nag asook onder alle weersomstandighede voortgesit kan word. In die algelope dekade is Zn-6.5 en veral Co-60 en P-32 dikwels in sodanige eksperimente gehruik. terwyl Kaye 11960) onlangs ook Au198 suksesvol ingespan het. Hierdic outeur het muise met onderhuidsgeplaaste goud-108-draadjies gemerk en hulle bewegings met behulp van 'n draaghare Geiger-teller gevolg. Goud is in hierdie geval verkies omdat dit 'n kort halfleeftyd het. maar tog genoegsame gamma-energie vrystel. Die moontlikheid om soortgelyke metodes ook op groot wilde diere toe te pas, word tans ondersoek. Dit hou natuurlik veral groot praktiese implikasies vir wildlewaring in. want 'n kennis van die ekologie van diere in wildtuine is noodsaaklik om die hiologiese ewewig in sodanige natuurrescrvate te behou.

Dit bly egter noodsaaklik dat alle navorsing wat met behulp van die radio-isotooptegnieke uitgevoer word, baie versigtig heplan moet word. Hierdie isotope is beslis handige hulpmiddels vir sekere ondersoeke wat tot nou toe as onmoontlik beskou is, maar hulle is nie in alle gevalle beter as die goed-gevestigde konvensionele metodes nie. As gevolg van die toenemende gevare moet radioaktiewe spoorvormers met groot versigtiglecid gebruik word, en ook net in daardie ondersoeke waar loulle beslis die gewone metodes oorskadu. Hulle hou egter groot belofte in vir talle navorsingsprojekte waar tans nog geen ander bevredigende metodes ontdek is nie.

\section{IITHRATULRVERWYSINGS:}

AltERBACH, S. I. 19,58. The soil cosystem and radioactive waste dikposal to the grouncl. Ficol. 39: 522 529.

BARNES, M. M. 1959. Radiotracer labeling of a natural tephritid population and flight range of the walnut husk fly. Ann. rnt. Soc. Amer, 52: $90-92$. 
BALAMHOVER. A. If. el al. 1955. Sirew-worm control through release of sterilized Ilies. J. rcon. Finlom. 18: 162-166.

BliKRYMAN, A. A. and STARK. R. W. 1962. Radiography in forest entomology. Ann. ent. Soc. A mere. 3.5: 1.56-166.

BRROWN. R. F. el al. 19.56. Disposal of linguid wastes to the ground. Proc. Int. Conf. Peateeful Uses Atomic Finergy 9: 669-67.).

BRYANT, E. J. el al. 19.57. Radiostrontium in soil, orass, milk and bone in U.K.; 19.36 results. J. Nuclear Finergy 6: 22 ....

(ASTER, W. 0. 1957, Sitronsium-90) hazards: relationship belween maximum permissible concentration and population means. Science 12.5: 1291.

CoMAR. (: I. I95.5. Raclioisotopes in hiology and auriculture. Principles and praclice. Mediraw-llill Book Co.. Inc.. New York.

('()MAR. C. I.. (Kelit.) 1957. Atomic energy and agriculuture. Amer. Assoc. Adlv. Sri., Publ. No. 29: 1 - -50.

DENNIS. N. M. 1961. The effects of gamma-ray irradiation on cerlain species of slored-prosluel insecls. J. eron. Fint. 54: 211-213.

F(NSTFR, R. F. and I)AVIS, J. J. 19.56. The accumulation of radioactive substances in apuatic forms. Proc. int. Conf. peaceful Uses alomic Fnergy 13:364-367.

liRANCIS. 6. F. et al. 1959. Isolopie tracers. A theoretical and practical manual for biological siutents and research workers. Second edition. The Athlone Press, I/niv. London.

IIANSOIN. W. C. and KORNBERK;. IT. A. 1956. Raclioactivity in terrestrial animals near an atomic energy sile. Proc. int. Conf. peaceful l'ses atomic Finergy 13: 38.5388.

HOL.AENIDFR. A. (Filit). 195\%. Radiation biology. Vol. 1. High energy ralliation. Vol. II. Ultraviolel and related radiation. Vol. III. Visible and nearvisible light. Me(Graw-Itill Book (io., Inc., New York.

HITT IIINSONN. C. F. 19:57. A trealise on limnology. Vol. I. Iolın Wiley and Sons, Inc., New York.

JENKINS, D. W. 1957. Raclioisolopes in entomology in Comar 1957: Atomic energy and agriculture pl. $195-22 \%$.

KAYF, S. V. 1960. Gold-198 wires used to study movements of small mammals. Sicience 131: 821 .

KORNBER6; II. A. 19.58. Radiation biology as a supporting function for atomic cnergy installations. Proc. $2 n I$ int. Conf. praceful Ilses atomic Knergy. 18: 329333.

KRINIIOI.\%. 1.. A. 195.t. A summary of findings of the ecological survey of White (lak Creck. Roane County. Tennessee, 1950-1953. 11.S. Alomic Energy (omm.. P'ubl. ORO 132.

I.0ITIT, J. E. 1956. The experimental animal for the sturly of biologieal effects of ralliation. Proc. int. Conf. praceful Uses atomic Einergy 11: 3 -6.

NISIIIA. II, and I.ARSON. K. H1. 1957. Summary of cerlain Irentls in soil-plant relationship studies of the biological availability of fall-out debris. Univ. Calif. Ios Angeles. Atomic Fnergy Project Report No. Hol: 1--67.

(1)UUM. F. P. 19:99. Fundamenlals of ecolog!. Second Ealition. W. B. Saunders Co. Philadelphia and Iondon.

PRENILETON, R. C. 1956. I.abeling animals with radioisotopes. Ecology 37: $686 \ldots 689$

PUJCK, T. T. and MARCIIS, P. I. 19:56. Aclion of X.rays on mammalian cells. J. exp. Med. 103: 6.33 666 .

RoMNFY, F. M. It al. 19.57. Plant uptake of Sro0. Y91, Rulo6, Cs137 and Cel14 from soils. Soil Science 83: $369-376$. 


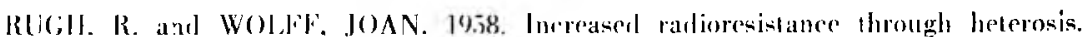
Sicince 127: 111 1 15.

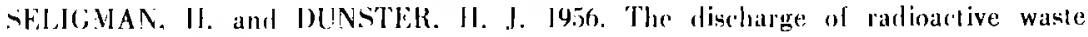
prorlucts into the lrish Soa. Proce int. Conf. peaceful lsess atomic Fnergy 9: 701701 .

VIIIEALA. J. B. el al. 1961 . Immunization 10 Schistosoma mansoni in miee inoculated with radiated cercariae. Sicience 134: 1073-1075.

voc,T. W. J. 1957. Alomic power for peace Vol. 3. Radioisotopes and tracers in industry agriculture, meteorology and medicione. Alomic Power Review. Johannesibury. 